\title{
Olimpia Marcewicz
}

Uniwersytet Marii Curie-Skłodowskiej

olimpia.marcewicz@gmail.com

\section{Ewelina Streit-Browarna}

Uniwersytet Marii Curie-Skłodowskiej

ewelina.streit-browarna@poczta.umcs.lublin.pl

\section{Zasada obowiązkowego wszczęcia administracyjnego postępowania egzekucyjnego a zasada dyspozytywności w sądowym postępowaniu egzekucyjnym - ujęcie prawnoporównawcze}

\author{
The Principle of Compulsory Initiation of Administrative \\ Enforcement Proceedings and the Principle of Dispositivness \\ in Court Enforcement Proceedings - Comparative \\ Law Conceptualization
}

\section{STRESZCZENIE}

\begin{abstract}
Niniejsze opracowanie to próba zaprezentowania problematyki najważniejszych zasad sądowego i administracyjnego postępowania egzekucyjnego w ujęciu porównawczym. Autorki omawiają zagadnienia związane $\mathrm{z}$ definiowaniem zasad prawa na tle każdej $\mathrm{z}$ tych procedur, wskazują na kryteria ich wyróżnienia oraz rolę zasad prawa w stanowieniu, wykładni i stosowaniu prawa. W dalszej kolejności została przedstawiona problematyka katalogów zasad, na które wskazuje się w doktrynie sądowego i administracyjnego postępowania egzekucyjnego, z zaakcentowaniem ich odrębności i specyfiki w porównaniu z innymi gałęziami prawa. W drugiej części opracowania została zaprezentowana analiza zasady dyspozytywności w sądowym postępowaniu egzekucyjnym oraz zasady obowiązkowego wszczęcia administracyjnego postępowania egzekucyjnego, a zatem zasad, które najlepiej obrazują odmienność reguł rządzących publicznym i prywatnym prawem egzekucyjnym.
\end{abstract}

Słowa kluczowe: zasada obowiązkowego wszczęcia postępowania; zasada dyspozytywności; zasady ogólne; administracyjne postępowanie egzekucyjne; sądowe postępowanie egzekucyjne 


\section{WSTĘP}

Zagadnienie zasad prawa stanowi istotny problem ogólnoteoretyczny i zarazem jest postrzegane jako kwestia o fundamentalnym znaczeniu w odniesieniu do każdej z gałęzi prawa. $Z$ tej przyczyny tematyka zasad prawa była podejmowana $\mathrm{w}$ doktrynie wielokrotnie i nieustająco powraca, co dotyczy również sądowej oraz administracyjnej procedury egzekucyjnej ${ }^{1}$. Wynika to przede wszystkim ze szczególnej roli zasad prawa, które - jak się podkreśla w literaturze - wyznaczają kierunek działań prawodawczych, determinują sposób interpretacji przepisów prawnych, wskazują kierunki stosowania prawa oraz ukierunkowują sposób czynienia użytku z różnych, przysługujących określonym podmiotom, praw².

\section{POJMOWANIE ORAZ ONTOLOGIA ZASAD PRAWA W ADMINISTRACYJNYM I SĄDOWYM POSTĘPOWANIU EGZEKUCYJNYM}

W doktrynie prawa administracyjnego zasady prawa postrzega się jako element systemu normatywnego, za pomocą którego ustawodawca wprowadza określone wartości o charakterze aksjologicznym, które trudno w inny sposób uchwycić $\mathrm{w}$ ramy normatywne ${ }^{3}$. U podstaw prowadzonych w literaturze przedmiotu rozważań leży koncepcja wypracowana przez J. Wróblewskiego wskazująca, że zasady prawa to wypowiedzi o charakterze dyrektywalnym ${ }^{4}$. W związku z tym, według stanowiska A. Skoczylasa, zasadami administracyjnego postępowania egzekucyjnego są tylko normy wypowiedziane w przepisach prawa wprost oraz normy będące ich logicznymi konsekwencjami

R. Hauser stwierdza przy tym: ,[...] wypowiedzi opisujące określone instytucje prawne (tj. funkcjonalnie powiązane zespoły norm), a także wypowiedzi oceniające rozwiązania prawne, choćby tylko pomyślane, zaliczamy do wypowiedzi o zasadach prawa (czyli do »meta-wypowiedzi«)" ${ }^{\circ}$. Nie oznacza to, że pojęcie zasad prawa powinno mieć charakter zawężający i obejmować wyłącznie

${ }^{1}$ Taką prawidłowość da się zauważyć nie tylko w polskim porządku prawnym, ale również w prawodawstwach większości państw. Zob. na ten temat: P. Pogonowski, Postępowanie zabezpieczajace i egzekucyjne, Warszawa 2007, s. 112.

${ }^{2}$ A. Redelbach, S. Wronkowska, Z. Ziembiński, Zarys teorii państwa i prawa, Warszawa 1993, s. 226.

${ }^{3}$ Zob. A. Skoczylas, Zasady postepowania egzekucyjnego, [w:] System prawa administracyjnego, t. 9: Prawo procesowe administracyjne, red. B. Adamiak, J. Borkowski, A. Skoczylas, Warszawa 2010, s. 383.

${ }^{4}$ Por. np. J. Nowacki, Z. Tabor, Wstęp do prawoznawstwa, Warszawa 1994, s. 92.

${ }^{5}$ A. Skoczylas, op. cit., s. 383.

${ }^{6}$ R. Hauser, Ochrona obywatela w postępowaniu egzekucyjnym w administracji, Poznań 1988, s. 50 . 
wypowiedzi normatywne posiadające walor obowiązujących norm prawa. Zasadą prawa może być wszakże zarówno konkretne rozwiązanie prawne obowiązujące w danym miejscu i czasie (zasady in concreto), jak i rozwiązanie prawne tylko pomyślane (zasady in abstracto) ${ }^{7}$. Jednocześnie należy pamiętać, że od zasad prawa trzeba odróżnić, po pierwsze, normy gwarantujące ich przestrzeganie, ergo nakazujące właściwym organom reagowanie na fakt nieprzestrzegania zasad, oraz, po drugie, normy realizujące zasady, ergo nakazujące zachowania niezbędne dla realizowania normy o zasadniczym znaczeniu czy też wskazujące środki najwłaściwsze $\mathrm{w}$ danych warunkach dla realizowania zasady ${ }^{8}$.

Inaczej niż $\mathrm{w}$ administracyjnym postępowaniu egzekucyjnym zasady prawa obecne w sądowym postępowaniu egzekucyjnym (tzw. zasady postępowania egzekucyjnego ${ }^{9}$ ) postrzega się silnie przez pryzmat zasad formułowanych na gruncie postępowania cywilnego, co - jak podkreśla A. Marciniak - ma swoje uzasadnienie funkcjonalne i normatywne ${ }^{10}$. Postępowanie egzekucyjne jest częścią szeroko rozumianego postępowania cywilnego, pozostaje z nim w ścisłym związku choćby z tej przyczyny, że realizuje wspólny cel, jakim jest urzeczywistnienie norm prawa cywilnego ${ }^{11}$. Dlatego też znajdą w nim zastosowanie zasady postępowania cywilnego $\mathrm{w}$ takim zakresie, $\mathrm{w}$ jakim da się je zrekonstruować z przepisów prawa odnoszących się do egzekucji i postępowania egzekucyjnego ${ }^{12}$ oraz z uwzględnieniem specyfiki tego postępowania. W konsekwencji poglądy prezentowane $\mathrm{w}$ odniesieniu do zasad postępowania cywilnego są odnoszone wprost do zasad postępowania egzekucyjnego.

W kwestii definiowania zasad postępowania cywilnego zauważa się, że w nauce procesu cywilnego są prezentowane dwa odmienne ujęcia - dyrektywalne i opisowe ${ }^{13}$, można również spotkać ujęcie kombinowane, łączące elementy obu

${ }^{7}$ Ibidem.

${ }^{8}$ Ibidem, s. 51.

${ }^{9}$ Zob. np. J. Korzonek, Postępowanie egzekucyjne i zabezpieczające. Część druga kodeksu posteppowania cywilnego, t. 1: Art. 508-597, Kraków 1934, s. 530; F. Kruszelnicki, Zarys systemu polskiego prawa egzekucyjnego i zabezpieczającego, Warszawa 1934, s. 75; A. Marciniak, Sąowe postępowanie egzekucyjne, wyd. 2, Warszawa 2013, s. 33. Warto nadmienić, że pojęcie zasad postępowania egzekucyjnego nawiązuje do pojęcia zasad postępowania cywilnego. Tradycyjnie bowiem zasady prawa $\mathrm{w}$ procedurze cywilnej określa się mianem zasad procesu cywilnego lub zasad postępowania cywilnego, choć z teoretycznego punktu widzenia trafniejsze i bardziej precyzyjne byłoby określenie „,zasady prawa procesowego cywilnego” (J. Jodłowski, Wstęp do systemu prawa procesowego cywilnego, [w:] Zbiór studiów, red. J. Jodłowski, Wrocław 1974, s. 57).

${ }^{10}$ A. Marciniak, op. cit., s. 33. Zob. także: E. Wengerek, Egzekucja sądowa (studium na tle projektu k.p.c. PRL), „Annales UMCS. Sectio G” 1957, Vol. IV, z. 4, s. 286.

${ }^{11}$ A. Marciniak, op. cit., s. 33; E. Wengerek, Sadowe postępowanie egzekucyjne w sprawach cywilnych, Warszawa 1978, s. 40.

${ }^{12}$ P. Pogonowski, op. cit., s. 112.

${ }^{13}$ Szerzej na temat dyrektywalnego i opisowego rozumienia zasad prawa zob. np. M. Kordela, Zasady prawa. Studium teoretyczno-prawne, Poznań 2012, s. 23 i n.; G. Maroń, Zasady prawa. Poj- 
poprzednich. Zasady w ujęciu opisowym są rozumiane jako pewne sposoby lub wzorce, według których należy rozwiązywać kluczowe dla prawa procesowego problemy, natomiast $\mathrm{w}$ ujęciu dyrektywalnym zasady pojmuje się jako normy mające dla postępowania cywilnego nadrzędne znaczenie ${ }^{14}$. Definicja zasad postępowania egzekucyjnego, zaproponowana przez A. Marciniaka, nawiązuje do poglądów wyrażanych na gruncie procesu cywilnego i wydaje się prezentować ujęcie kombinowane (dyrektywalno-opisowe): ,[...] zasady postępowania egzekucyjnego to wyrażone w normach prawa egzekucyjnego podstawowe idee i założenia, które legły u podstaw ustawowego kształtowania struktury postępowania egzekucyjnego, jego poszczególnych przepisów i instytucji”"15.

Podejmując próbę uściślenia kryteriów wyróżniających zasady postępowania cywilnego, wskazuje się, że mają charakter wiodących (naczelnych) idei przewodnich albo założeń podstawowych postępowania, pozostają wyrażone w normach prawa procesowego, odnoszą się do całości postępowania (tj. wszystkich jego instytucji) oraz wskazują metody i sposoby realizacji jego celów (funkcji) ${ }^{16}$. Podobnie jak w doktrynie postępowania administracyjnego, liczni autorzy szczególny nacisk kładą na normatywny charakter zasad postępowania cywilnego, podkreślając, że postulaty ustawodawcy muszą być wyrażone w konkretnej normie prawnej (wynikającej z jednego przepisu prawa albo będącej wynikiem zestawienia pewnego zespołu przepisów $)^{17}$. J. Jodłowski zaznacza, że dopiero połączenie postulatu ustawodawcy z systemem gwarancji zabezpieczających jego realizację, zawartych w innych normach, pozwala na to, by uznać zasadę zadeklarowaną $\mathrm{w}$ danym przepisie za zasadę naczelną ${ }^{18}$.

\section{ROLA ZASAD PRAWA W WYKŁADNI I STOSOWANIU PRAWA W ADMINISTRACYJNYM I SĄDOWYM POSTĘPOWANIU EGZEKUCYJNYM}

Doniosłość problematyki zasad prawa w nauce procesu cywilnego można dostrzec w potrzebie wyróżnienia zasad naczelnych. W. Siedlecki określa je jako

mowanie i typologie a rola $w$ wykładni prawa i orzecznictwie konstytucyjnym, Poznań 2011, s. 73 i n.; A. Redelbach, S. Wronkowska, Z. Ziembiński, op. cit., s. 224-225.

${ }^{14}$ K. Piasecki, Postepowanie sporne rozpoznawcze, Warszawa 2004, s. 46 i n. Autor uważa, że na gruncie prawa procesowego cywilnego bardziej właściwe jest ujęcie opisowe. Podobne przekonanie wyraził Ł. Błaszczak ([w:] Postępowanie cywilne, red. E. Marszałkowska-Krześ, wyd. 2, Warszawa 2011, s. 52)

${ }^{15}$ A. Marciniak, op. cit., s. 33.

${ }^{16}$ J. Jodłowski, op. cit., s. 54 i n. Zob. także: Z. Resich, Istota procesu cywilnego, Warszawa 1985, s. 118 i n.

${ }^{17}$ K. Korzan, Sadowe postepowanie zabezpieczajace $i$ egzekucyjne $w$ sprawach cywilnych, Warszawa 1986, s. 113-114.

${ }^{18}$ J. Jodłowski, Z. Resich, Postępowanie cywilne, Warszawa 1987, s. 127; J. Jodłowski, op. cit., s. $55-56$. 
centralne idee systemu procesowego, znajdujące swoje odbicie w poszczególnych instytucjach i przepisach procesowych, które decydują o charakterze postępowania sądowego i warunkują spełnienie zadań zakreślonych temu postępowaniu ${ }^{19}$. Podkreśla się również, że zasady procesowe, w tym zasady postępowania egzekucyjnego, są pewnymi standardami funkcjonowania wymiaru sprawiedliwości i poszczególnych procedur ${ }^{20}$, stanowią dyrektywy sprawności postępowania zapewniające wypełnienie jego funkcji przez właściwe załatwianie spraw, których postępowanie dotyczy ${ }^{21}$. Zasady te wskazują, jak ustawodawca winien racjonalnie unormować przebieg postępowania, a następnie dla podmiotów uczestniczących w postępowaniu - jak powinny interpretować przepisy prawa procesowego, aby ich działanie oparte na tych przepisach prowadziło sprawnie do zrealizowania w konkretnej sprawie ogólnej funkcji postępowania ${ }^{22}$.

Podobnie szczególna rola zasad prawa na gruncie administracyjnego postępowania egzekucyjnego polega nie tylko na wyznaczaniu kierunku działań prawodawczych, ale przede wszystkim na ukierunkowywaniu procesu interpretacji przepisów prawa. W tym kontekście podkreśla się ogromną rolę zasad na etapie decyzji walidacyjnej. Wprawdzie zasady nie są traktowane jako samoistny argument walidacyjny, lecz uwypuklenie ich znaczenia w ramach regulacji prawnych dotyczących administracyjnego postępowania egzekucyjnego będzie istotne przy zadecydowaniu, które z branych pod uwagę przepisów prawnych znajdą zastosowanie i staną się podstawą rozstrzygnięcia ${ }^{23}$. Zasady prawa są zatem czynnikiem mającym wpływ na proces rekonstrukcji normatywnej podstawy decyzji, dlatego problemem jest ich stosowanie w sytuacji odesłania przez nie do kryteriów o charakterze pozaprawnym, jak np. kryterium najmniej uciążliwego środka egzekucyjnego dla zobowiązanego.

Znaczenie zasad prawa na gruncie administracyjnej procedury egzekucyjnej podkreśla również judykatura, która upatruje w nich drogowskazu wytyczającego kierunek stosowania prawa (w szczególności sposób czynienia użytku z tzw. luzów decyzyjnych) oraz wyznaczającego sposób postrzegania przysługujących różnym podmiotom praw i roszczeń ${ }^{4}$. Zasady prawa są zatem czynnikiem porządkującym normy prawne kształtujące dane instytucje oraz harmonizującym procesy wykładni przepisów po to, by system prawny tworzył funkcjonalnie po-

${ }^{19}$ Autor zwraca też uwagę na kluczowe znaczenie tych zasad w świetle orzecznictwa sądowego - zob. W. Siedlecki, Postępowanie cywilne. Zarys wyktadu, Warszawa 1987, s. 57-58; idem, Zasady wymiaru sprawiedliwości i naczelne zasady procesu cywilnego w świetle orzecznictwa $S N$, „Zeszyty Naukowe IBPS" 1978, nr 10, s. 46 i n.

${ }^{20}$ K. Piasecki, op. cit., s. 46.

${ }^{21}$ W. Broniewicz, Postepowanie cywilne w zarysie, Warszawa 2008, s. 55.

${ }^{22}$ W. Berutowicz, Postepowanie cywilne w zarysie, Warszawa 1984, s. 271.

${ }^{23}$ J. Skoczylas, op. cit., s. 385.

${ }^{24}$ Por. wyrok Wojewódzkiego Sądu Administracyjnego w Gorzowie Wielkopolskim z dnia 30 października 2008 r., I SA/Go 678/08. 
wiązaną całość. W literaturze przedmiotu podkreśla się przy tym, że zasady administracyjnego postępowania egzekucyjnego winny być rozpatrywane nie tylko samodzielnie, ale również jako zasady części systemu prawa, ponieważ właściwa egzegeza przepisów regulujących daną materię nie jest możliwa bez uwzględnienia zasad ogólnych prawa ${ }^{25}$.

W celu przedstawienia najważniejszych czynników kształtujących konstrukcję zasad prawa zarówno w odniesieniu do sądowego, jak i administracyjnego postępowania egzekucyjnego sięga się do koncepcji opartej na kryterium hierarchii norm systemu prawnego w dwóch jego poziomach - normach wynikających z Konstytucji Rzeczypospolitej Polskiej z dnia 2 kwietnia 1997 r. (Dz. U., nr 78, poz. 483 z późn. zm.) oraz normach warstwy regulacji ustawowej. Przejawem znaczenia postanowień Konstytucji dla regulacji administracyjnego postępowania egzekucyjnego jest przede wszystkim wpływ licznych unormowań aktu zasadniczego na proces wykładni przepisów ustawy. W szczególności regulacja Rozdziału I Konstytucji RP, zawierająca zasady ustrojowe państwa, ale również jej normy szczegółowe mają znaczenie przy budowie konstrukcji prawnych $\mathrm{w}$ zakresie tego postępowania ${ }^{26}$. Podobnie na gruncie cywilnego prawa procesowego akcentuje się szczególną rolę Konstytucji RP dla standardów funkcjonowania procedury wykonawczej, co znajduje odzwierciedlenie w wyróżnieniu odrębnego katalogu zasad ustrojowych (konstytucyjnych) odnoszących się do postępowania wykonawczego ${ }^{27}$.

\section{KATALOGI PODSTAWOWYCH ZASAD ADMINISTRACYJNEJ ORAZ SĄDOWEJ PROCEDURY EGZEKUCYJNEJ}

Zasady znajdujące zastosowanie w administracyjnym postępowaniu egzekucyjnym na płaszczyźnie ustawowej są zawarte w dwóch zespołach regulacji. Podstawowym unormowaniem jest ustawa z dnia 17 czerwca 1966 r. o postępowaniu egzekucyjnym w administracji ${ }^{28}$. Cechą wyróżniającą ten akt jest brak osobnych norm o charakterze generalnym będących zasadami prawa. W przeciwieństwie do

${ }^{25}$ Por. K. Ziemski, Zasady ogólne prawa administracyjnego, Poznań 1989, s. 62.

${ }^{26}$ Por. M. Szubiakowski, Zasady ogólne administracyjnego postępowania egzekucyjnego, [w:] System egzekucji administracyjnej, red. J. Niczyporuk, S. Fundowicz, J. Radwanowicz, Warszawa 2004, s. 120. Autor podkreśla, że odrębną kwestią jest udzielenie odpowiedzi na pytanie, czy normy Konstytucji wywołują samodzielny skutek w obrębie administracyjnego postępowania egzekucyjnego. Jak stwierdza bowiem M. Szubiakowski, „wydaje się, że nie ma wiele z przepisów ustawy zasadniczej, które zawierałyby tak szczegółowe normy odnoszące się do postępowania egzekucyjnego, aby mogła ona być stosowana bezpośrednio jako zasada postępowania egzekucyjnego. Cechę taką można przypisać normom o szerokim zakresie oddziaływania, a co za tym idzie związanym z postępowaniem egzekucyjnym jedynie zakresem tego oddziaływania" (por. ibidem, s. 121).

${ }^{27}$ Zob. szerzej na ten temat m.in. K. Korzan, op. cit., s. 114 i n.

${ }^{28}$ T.j. Dz. U. z 2005 r., nr 229, poz. 1954 z późn. zm., dalej: u.p.e.a. 
innych procedur - karnej czy cywilnej - w których zasady ogólne stanowią wyodrębnioną jednostkę redakcyjną aktów normatywnych je regulujących, ukształtowanie zasad ogólnych administracyjnego postępowania egzekucyjnego jest wytworem jurysprudencji ${ }^{29}$. Wprawdzie ustawodawca zawarł je w Dziale I ustawy w rozdziale pt. Zasady ogólne, jednakże normy, jakie się w nim znalazły, dotyczą raczej zakresu podmiotowego i przedmiotowego stosowania ustawy. Zasadami ogólnymi na gruncie ustawy o postępowaniu egzekucyjnym w administracji są jej szczegółowe postanowienia, które z powodu funkcji i znaczenia zostały uznane w doktrynie i judykaturze za zasady ogólne. Unormowania ustawy o postępowaniu egzekucyjnym w administracji, które pełnią rolę zasad, spełniają zatem jednocześnie również inne funkcje proceduralne polegające na określeniu konkretnych obowiązków podmiotów biorących udział w postępowaniu. W konsekwencji powyższego zasady zawarte $\mathrm{w}$ przedmiotowej ustawie - w stosunku do zasad wyrażonych w innych aktach normatywnych - charakteryzują się stosunkowo dużym stopniem konkretności i są określane niekiedy zbiorczym pojęciem „zasad o różnym stopniu abstrakcyjności" ${ }^{30}$.

Drugą warstwę regulacji ustawowej zawiera ustawa z dnia 14 czerwca $1960 \mathrm{r}$. - Kodeks postępowania administracyjnego ${ }^{31}$, która w postępowaniu egzekucyjnym - w oparciu o art. 18 u.p.e.a. - znajduje odpowiednie zastosowanie. Możliwość posłużenia się zasadami kodeksu w postępowaniu egzekucyjnym jest jednak znacznie ograniczona. Normuje on bowiem procedurę orzeczniczą, zaś postępowanie egzekucyjne obejmuje przede wszystkim czynności faktyczne organów egzekucyjnych. Należy przy tym podkreślić, że zasady wynikające z k.p.a. mogą być stosowane $\mathrm{w}$ postępowaniu egzekucyjnym tylko $\mathrm{w}$ takim zakresie $\mathrm{i} \mathrm{w}$ taki sposób, aby uzupełnić, ale nie modyfikować przepisów u.p.e.a. ${ }^{32}$ Zastosowanie przepisów k.p.a. w administracyjnym postępowaniu egzekucyjnym nie pozbawia ich charakteru zasad postępowania jurysdykcyjnego i nie nadaje im charakteru zasad postępowania wykonawczego, dlatego możliwość nazywania ich zasadami administracyjnego postępowania egzekucyjnego jest poddawana w literaturze W wątpliwość ${ }^{33}$.

W nawiązaniu do powyższych rozważań należy skonkludować, że w doktrynie są proponowane różne klasyfikacje zasad ogólnych administracyjnego postępowania egzekucyjnego, które zależą od przyjętych kryteriów stanowiących

${ }^{29}$ P. Krzykowski, Funkcje zasad ogólnych Kodeksu postępowania administracyjnego, [w:] Kodyfikacja postępowania administracyjnego. Na 50-lecie Kodeksu postęowania administracyjnego, red. J. Niczyporuk, Lublin 2010, s. 440.

${ }^{30}$ Por. K. Ziemski, op. cit., s. 43-44.

${ }^{31}$ T.j. Dz. U. z 2013 r., poz. 267 z późn. zm.

32 Por. wyrok Naczelnego Sądu Administracyjnego z dnia 25 kwietnia 2003 r., III SA 2585/02, LEX nr 148901.

${ }^{33}$ Zob. M. Szubiakowski, op. cit., s. 123. 
podstawę ich wyodrębnienia ${ }^{34}$. Katalog zasad tego postępowania nie ma bowiem charakteru normatywnego, a nazwy zasad nie zostały w sposób autorytatywny narzucone przez ustawodawcę. Są one dekodowane z dorobku nauki prawa administracyjnego i orzecznictwa sądów administracyjnych.

Optując za tezą, iż zasadami administracyjnego postępowania egzekucyjnego sensu stricto są tylko te, które można wyinterpretować z norm ustawy o postępowaniu egzekucyjnym $\mathrm{w}$ administracji, wymienia się następujące zasady ogólne: celowości, obowiązkowego wszczęcia administracyjnego postępowania egzekucyjnego, zagrożenia, niezbędności, poszanowania minimum egzystencji, prowadzenia egzekucji w porze najdogodniejszej dla zobowiązanego, gospodarnego prowadzenia egzekucji, niezależności środków egzekucyjnych, stosowania najłagodniejszego środka egzekucyjnego, stosowania środków egzekucyjnych przewidzianych w ustawie, stosowania środków egzekucyjnych prowadzących bezpośrednio do wykonania obowiązku oraz stosowania środków najmniej uciążliwych dla zobowiązanego. Warto przy tym dodać, że dwie ostatnie z wymienionych zasad $w$ judykaturze zostają niekiedy zastąpione zbiorczą nazwą i są określane jako zasada racjonalnego działania ${ }^{35}$.

Co do tego, która z wyżej wymienionych zasad jest tą najważniejszą nie ma w literaturze zgody. Determinantem takiego stanu rzeczy jest fakt, że administracyjne postępowanie egzekucyjne to w istocie ,zderzenie się" dwóch niejednokrotnie sprzecznych ze sobą interesów - publicznego i indywidualnego. Spojrzenie na administracyjną procedurę egzekucyjną z perspektywy ochrony praw zobowiązanego nakazuje stwierdzić, że „w państwie demokratycznym, szanującym wolności i prawa człowieka, skuteczność egzekucji nie jest wartością najwyższą"36. Mając jednak na względzie, że postępowanie to służy doprowadzeniu do zgodności stanu faktycznego ze stanem prawnym, zasadny wydaje się wniosek, iż przestrzeganie zasad etycznych tylko wyjątkowo może przeszkodzić w osiągnięciu celu egzekucji ${ }^{37}$. Nie ulega wątpliwości, że rolą zasad ogólnych administracyjnego postępowania egzekucyjnego jest zapewnienie poszanowania reguł sprawiedliwej procedury $-\mathrm{z}$ jednej strony przez zapewnienie skuteczności stosowanego przymusu, a z drugiej - w zakresie gwarantowania odpowiedniej ochrony praw-

${ }^{34}$ Zob. J. Starościak, Podstawowe zagadnienia postępowania egzekucyjnego w administracji, „Gospodarka i Administracja Terenowa” 1966, nr 7-8 (wkładka), s. 26; M. Szubiakowski, op. cit., s. 124 i n.; R. Hauser, op. cit., s. 52 i n.

${ }^{35}$ Por. wyrok Wojewódzkiego Sądu Administracyjnego w Gdańsku z dnia 15 kwietnia 2009 r., II SA/Gd 907/08, Baza NSA.

${ }^{36}$ E. Smoktunowicz, Egzekucja administracyjna i sąowa. Teksty, orzecznictwo, piśmiennictwo, indeks rzeczowy, Warszawa 1995, s. 20.

${ }^{37}$ Por. P. Szreniawski, Etyczne aspekty egzekucji administracyjnej, [w:] System egzekucji..., s. 45 . 
nej zobowiązanemu ${ }^{38}$. Takie ujęcie funkcji zasad ogólnych postępowania pozwala na stwierdzenie, że kwestia ewentualnej kolizji między zasadami oraz zasadami a innymi konstrukcjami normatywnymi jest problemem nieistniejącym.

Odnosząc się do problematyki katalogu zasad sądowego postępowania egzekucyjnego, w literaturze przedmiotu można zaobserwować dwa odmienne podejścia do tego zagadnienia. Niektórzy autorzy, zwłaszcza okresu dwudziestolecia międzywojennego ${ }^{39}$, przejawiali tendencję do wskazywania ,zasad egzekucji sądowej odrębnych od zasad procesu cywilnego"40. Przykładowo J. Korzonek i F. Kruszelnicki wyróżniali zasadę postępowania na wniosek (wolnej rozprawy stron) oraz zasadę postępowania z urzędu, ustności i pisemności ${ }^{41}$. Ponadto F. Kruszelnicki wskazywał też na zasadę jawności oraz zasadę jednostronnego postępowania ${ }^{42}$. Z kolei W. Miszewski nie mówił wprost o zasadach postępowania egzekucyjnego, lecz o ogólnych założeniach prawa egzekucyjnego, mając na myśli założenia, które stanowią , czynnik koordynujący poszczególne grupy norm postępowania, jak również ich całość". Nie prezentował enumeratywnego katalogu, lecz „ważniejsze z tych założeń”, a wśród nich: zapewnienie wierzycielowi zaspokojenia roszczeń przy użyciu środków racjonalnych, ochronę interesów dłużnika, ochronę osób trzecich, wzgląd na stosunki gospodarcze i społeczne, wzgląd na stosunki międzynarodowe, zasadę dyspozycyjności w zakresie wszczęcia i popierania egzekucji oraz koncentrację egzekucji43.

Odmienne od powyższego podejście zaproponowano w publikacjach powojennych, gdzie przyjmowano, że zasady postępowania egzekucyjnego zasadniczo pozostają zbieżne $\mathrm{z}$ naczelnymi zasadami postępowania cywilnego, dlatego należy je analizować w tym właśnie kontekście ${ }^{44}$. Podkreślano zarazem, że specyfika postępowania wykonawczego sprawia, iż nie wszystkie zasady procesu cywilnego znajdą odzwierciedlenie w sądowym postępowaniu egzekucyjnym ${ }^{45}$.

E. Wengerek i K. Korzan zgodzili się, że w sądowym postępowaniu egzekucyjnym w mniejszym lub większym stopniu zachowują aktualność następujące zasady procesowe: prawdy obiektywnej, współdziałania stron i uczestników postępowania egzekucyjnego, dyspozycyjności (kontrolowanej rozporządzalności), równości, ustności i pisemności, formalizmu, jawności oraz swobodnej oceny do-

${ }^{38}$ R. Hauser, A. Skoczylas, Rola zasad ogólnych postępowania administracyjnego w postępowaniu egzekucyjnym w administracji, [w:] Kodyfikacja postępowania administracyjnego..., s. 56.

${ }^{39}$ M. Allerhand, Egzekucja sądowa. Stenogram wykładów, 1929, s. 92, cyt. za: E. Wengerek, Egzekucja sadowa ..., s. 286; F. Kruszelnicki, op. cit., s. 75; W. Miszewski, Proces cywilny w zarysie. Część druga, Łódź 1948, s. 30.

${ }^{40}$ E. Wengerek, Egzekucja sadowa ..., s. 286.

${ }^{41}$ J. Korzonek, op. cit., s. 530-532; F. Kruszelnicki, op. cit., s. 75-78.

${ }^{42}$ F. Kruszelnicki, op. cit., s. 75-78.

${ }^{43}$ W. Miszewski, op. cit., s. 30

${ }^{44}$ E. Wengerek, Egzekucja sadowa ..., s. 286.

${ }^{45}$ K. Korzan, op. cit., s. 114. 
wodów $^{46}$. E. Wengerek wyróżnił ponadto zasadę ochrony dłużnika ${ }^{47}$. K. Korzan obok zasad procesowych, cechujących także sądowe postępowanie egzekucyjne, podkreślał, że w postępowaniu tym realizowana jest również ustrojowa (konstytucyjna) zasada praworządności oraz że istnieje szereg tzw. zasad konstrukcyjnych, które odnoszą się do poszczególnych instytucji prawa egzekucyjnego cywilnego, wśród których szczególne znaczenie ma zasada proporcjonalności.

Poglądy prezentowane w najnowszym piśmiennictwie stanowią kontynuację koncepcji powojennych. Obecnie przyjmuje się, że skoro postępowanie egzekucyjne stanowi składową szeroko pojętego postępowania cywilnego, to idee przewodnie tego ostatniego znajdą zastosowanie również w odniesieniu do cywilnej procedury egzekucyjnej ${ }^{48}$.

A. Marciniak wyróżnia dwie podstawowe zasady sądowego postępowania egzekucyjnego, a mianowicie zasadę dyspozycyjności i zasadę formalizmu postępowania, stwierdzając zarazem, że inne naczelne zasady postępowania cywilnego także są obecne w postępowaniu egzekucyjnym, jednak w ograniczonym zakresie, co pozostaje uzasadnione jego specyfiką ${ }^{49}$. W szczególności wskazuje na zasady: prawdy, kontradyktoryjności, równouprawnienia stron lub uczestników postępowania, bezpośredniości, koncentracji materiału procesowego, ustności i pisemności oraz inicjatywy organów procesowych i egzekucyjnych co do toku postępowania. Podobnie P. Pogonowski do najważniejszych w postępowaniu egzekucyjnym zalicza zasady dyspozycyjności i formalizmu, lecz obok nich wymienia też konstytucyjnie gwarantowane zasady: poszanowania godności ludzkiej oraz prawa do wysłuchania (jako element prawa do sądu) ${ }^{50}$.

Reasumując powyższe uwagi dotyczące zasad prawa w sądowej i administracyjnej procedurze egzekucyjnej, trzeba podkreślić, że z uwagi na specyfikę administracyjnej procedury egzekucyjnej zasad ogólnych tego postępowania de facto nie można porównać z zasadami żadnej innej gałęzi prawa, chociaż z perspektywy istoty administracyjnego postępowania egzekucyjnego, którą jest stosowanie przymusu, najbardziej zbliżone do tej procedury jest niewątpliwie sądowe postępowanie egzekucyjne. Porównanie obydwu postępowań już na etapie ich wszczęcia ukazuje prima facie odmienność i zarazem indywidualność zasad odnoszących się do tej kwestii.

${ }^{46}$ Ibidem, s. 113 i n.; E. Wengerek, Sądowe postepowanie egzekucyjne..., s. 40 i n.; idem, Egzekucja sądowa..., s. 286 i n.

${ }^{47}$ E. Wengerek, Sądowe postepowanie egzekucyjne..., s. 40 i n.; idem, Egzekucja sądowa..., s. 286 i n.

${ }^{48}$ P. Pogonowski, op. cit., s. 111 i n.

${ }^{49}$ A. Marciniak, op. cit., s. 34-35.

${ }^{50}$ P. Pogonowski, op. cit., s. 111 i n. 


\section{ZASADA DYSPOZYCYJNOŚCI EGZEKUCJI SĄDOWEJ I ZASADA OBOWIĄZKOWEGO WSZCZĘCIA EGZEKUCJI ADMINISTRACYJNEJ}

W doktrynie cywilnego prawa procesowego panuje powszechne przekonanie, że zasada dyspozycyjności (rozporządzalności) należy do najważniejszych zasad sądowego postępowania egzekucyjnego ${ }^{51}$, na co wskazuje choćby to, że mimo różnic $\mathrm{w}$ poglądach nie została pominięta w żadnym z katalogów prezentowanych w piśmiennictwie przez różnych autorów. Zgoda panuje również, gdy chodzi o treść tej zasady. W aspekcie materialnym dyspozycyjność wyraża się w możności swobodnego rozporządzania przez strony (uczestników) przedmiotem postępowania, zaś w aspekcie formalnym - rozporządzalnością środkami procesowymi (zaczepnymi i obronnymi) w postępowaniu egzekucyjnym ${ }^{52}$. Zdaniem A. Marciniaka zasada dyspozycyjności, która cechuje całe postępowanie cywilne, najsilniej dochodzi do głosu właśnie w postępowaniu egzekucyjnym. Dotyczy to zarówno postępowania o nadanie klauzuli wykonalności, jak i tzw. właściwego postępowania egzekucyjnego ${ }^{53}$.

Zasada dyspozycyjności nie została wprost wyrażona w jednym konkretnym przepisie prawa, lecz jest rekonstruowana $\mathrm{z}$ szeregu norm prawa procesowego cywilnego i prawa egzekucyjnego. W doktrynie wyraźnie akcentuje się prymat zasady dyspozycyjności w stosunku do innych zasad postępowania egzekucyjnego, który przede wszystkim wynika stąd, że podstawowym celem tego postępowania jest zaspokojenie wierzyciela i dlatego jest on jego głównym dysponentem ${ }^{54}$. Regułą jest, że to właśnie od jego inicjatywy zależy wszczęcie postępowania klauzulowego oraz wszczęcie samej egzekucji (wyjątki przewidujące możliwość wszczęcia egzekucji z urzędu są podyktowane potrzebą ochrony niektórych kategorii wierzycieli, np. alimentacyjnych). Dlatego też, jak zaznacza K. Korzan, $\mathrm{w}$ postępowaniu egzekucyjnym (inaczej niż w cywilnym postępowaniu rozpoznawczym) chodzi głównie o rozporządzalność wierzyciela ${ }^{55}$.

Szeroki zakres uprawnień wierzyciela decyduje o znaczeniu zasady rozporządzalności w sądowym postępowaniu egzekucyjnym. Wyraża się także w tym, że ustawodawca pozostawił wierzycielowi nie tylko swobodę w zakresie inicjowania egzekucji, ale dał mu również pełną uznaniowość w kwestii zakończenia postępowania wykonawczego oraz znaczący wpływ na jego bieg - wierzyciel zawsze może czasowo powstrzymać egzekucję albo definitywnie ją zakończyć. Istotnym

\footnotetext{
${ }^{51}$ A. Marciniak, op. cit., s. 34, P. Pogonowski, op. cit., s. 112.

${ }^{52}$ A. Marciniak, op. cit., s. 35.

${ }^{53}$ Ibidem.

${ }^{54}$ K. Korzan, op. cit., s. 123-124; A. Marciniak, op. cit., s. 34; E. Wengerek, Sadowe postępowanie egzekucyjne..., s. 40.

${ }^{55}$ K. Korzan, op. cit., s. 123.
} 
przejawem zasady dyspozycyjności są przepisy o zawieszeniu i umorzeniu postępowania egzekucyjnego, wprowadzające niczym nieograniczone uprawnienie wierzyciela do żądania zawieszenia albo umorzenia tego postępowania. Wniosek wierzyciela w tym zakresie nie wymaga spełnienia jakichkolwiek dodatkowych wymogów, w szczególności nie podlega uzasadnieniu ani jakiejkolwiek kontroli ze strony organu egzekucyjnego. Organ egzekucyjny zawsze jest związany wnioskiem wierzyciela o zawieszenie albo o umorzenie postępowania.

Najlepiej jednak zasadę dyspozycyjności ilustruje brzmienie art. 822 k.p.c., który w szczególny sposób normuje obowiązki organu egzekucyjnego i uprawnienia wierzyciela w sytuacji, gdy dłużnik składa niebudzący wątpliwości dowód na piśmie, że egzekwowane roszczenie spełnił albo że wierzyciel udzielił mu zwłoki. W tej sytuacji organ egzekucyjny nie może zawiesić postępowania ani tym bardziej go umorzyć czy zakończyć egzekucji w związku z zaspokojeniem wierzyciela. Jedyne, do czego organ ten jest obowiązany, to wstrzymać się z dokonaniem czynności i zwrócić się do wierzyciela o podjęcie decyzji, czy ma nadal prowadzić egzekucję. Tylko wyraźna dyspozycja wierzyciela może doprowadzić do zakończenia postępowania, a jeśli takiej nie podejmie, organ egzekucyjny będzie miał obowiązek kontynuować egzekwowanie wierzytelności.

Administracyjnym postępowaniem egzekucyjnym rządzi zasada obowiązkowego jego wszczęcia, nazywana niekiedy zasadą prawnego obowiązku podjęcia przez wierzyciela odpowiednich kroków w celu wdrożenia egzekucji lub zasadą obligatoryjnego podejmowania egzekucji ${ }^{56}$. Ważkość tej zasady wynika z idei egzekucji pojmowanej jako jeden z elementów zmierzających do naprawy państwa.

Uzasadnienia tej zasady doktryna upatruje w przepisach Konstytucji RP. Za kluczowe uważane są zwłaszcza dwa przepisy. Po pierwsze, wskazuje się na treść art. 84 Konstytucji RP przewidującego obowiązek ponoszenia ciężarów publicznych, który określa się jako podstawową wytyczną dla dokonania oceny potrzeby i zasadności wszczynania postępowania egzekucyjnego ${ }^{57}$. Po drugie, zasadę obowiązkowego wszczynania egzekucji uważa się za przejaw realizacji konstytucyjnej zasady praworządności wyrażonej w art. 7 Konstytucji RP. Istnienie obowiązku w sferze prawa publicznego domaga się bowiem jego wykonania, dlatego wierzyciel powinien kontrolować wykonywanie obowiązków przez zobowiązanego. Ów stan czujności wierzyciela rozpoczyna się z chwilą nabycia przez obowiązek cechy wykonalności, zaś kończy się wraz z wygaśnięciem obowiązku zobowiązanego lub stwierdzeniem jego bezprzedmiotowości ${ }^{58}$.

Normatywnym wyrazem zasady obowiązkowego wszczęcia administracyjnego postępowania egzekucyjnego jest art. $6 \S 1$ u.p.e.a. nakazujący wierzycielo-

${ }^{56}$ Tak: R. Hauser, op. cit., s. 53; M. Szubiakowski, op. cit., s. 124.

${ }^{57}$ Por. M. Szubiakowski, op. cit., s. 121.

${ }^{58} \mathrm{~S}$. Fundowicz, Egzekucja administracyjna a aksjologia demokratycznego państwa prawnego, [w:] System egzekucji..., s. 39. 
wi określone zachowanie, tj. podjęcie czynności zmierzających do zastosowania środków egzekucyjnych w razie uchylania się przez zobowiązanego od wykonania obowiązku. Rola tej zasady została podkreślona przez M. Szubiakowskiego, który stwierdził, że „,wprowadzenie takiej normy jest wynikiem założenia, że niewykonanie ustalonego $\mathrm{w}$ orzeczeniu lub wynikającego $\mathrm{z}$ mocy prawa obowiązku podważa sens jego wprowadzania lub orzekania. Brak wykonania obowiązku administracyjnego podważa też sens zasady legalności i zasady zagrożenia" ${ }^{59}$. Omawiana zasada stanowi zatem swoiste preludium dla funkcjonowania pozostałych zasad administracyjnego postępowania egzekucyjnego, w tym również tych zasad, które mają bezpośredni lub pośredni związek z ochroną praw obywatela - zobowiązanego.

Z uwagi na ścisły związek z zaistnieniem sytuacji braku dobrowolnego wykonania przez zobowiązanego obowiązku publicznoprawnego, zasada prawnego obowiązku wszczęcia administracyjnego postępowania egzekucyjnego pełni trzy podstawowe funkcje. Pierwszą jest funkcja ochronna polegająca na zabezpieczaniu wartości uznanych ogólnie za istotne i pożądane. Drugą funkcję można określić jako kształtowanie świadomości społecznej o nieuchronności wykonania obowiązku podlegającego egzekucji administracyjnej. Trzecia z kolei to funkcja gwarancyjna polegająca na zabezpieczeniu realizacji obowiązków wykonywanych w drodze postępowania przymusowego.

Zasada obowiązkowego wszczęcia postępowania egzekucyjnego obliguje wierzyciela do podjęcia co najmniej kilku czynności mających na celu przymuszenie zobowiązanego do wykonania obowiązku. Z tego względu jej obecność jest wyraźnie akcentowana w procesie stosowania prawa. Należy wszak podkreślić, iż: „Jeśli ten, kogo nakaz czy zakaz dotyczy, nie chce się do niego zastosować, organ administracji musi mieć środki dla przeprowadzenia swojej woli, w przeciwnym razie wszelkie administrowanie byłoby niemożliwe" ${ }^{60}$. Zasada ta, służąc zapewnieniu skuteczności norm prawa publicznego, stanowi jednocześnie cechę charakterystyczną administracyjnego postępowania egzekucyjnego pozwalającą wyróżnić go spośród innych postępowań wykonawczych, a zwłaszcza przeciwstawić zasadom dotyczącym wszczęcia sądowego postępowania egzekucyjnego.

${ }^{59}$ M. Szubiakowski, op. cit., s. 124.

${ }^{60}$ M. Zimmermann, [w:] M. Jaroszyński, M. Zimmermann, W. Brzeziński, Polskie prawo administracyjne. Część ogólna, Warszawa 1956, s. 400, cyt. za: Z. Janku, Gwarancje prawne wykonywania obowiazków publicznoprawnych, [w:] Koncepcja systemu prawa administracyjnego. Zjazd Katedr Prawa Administracyjnego i Postępowania Administracyjnego. Zakopane 24-27 września 2006 r., red. J. Zimmermann, Warszawa 2007, s. 558. 


\section{PODSUMOWANIE}

Na koniec, odnosząc się do wszystkich powyższych uwag, warto zauważyć, że pojmowanie, ontologia i obowiązywanie zasad prawa na gruncie obydwu omawianych procedur wykonawczych wykazuje liczne podobieństwa. Sposób definiowania tych zasad jest dość zbliżony, podobnie akcentuje się najważniejsze kryteria wyróżniające, analogicznie pojmuje się rolę zasad prawa w wykładni i stosowaniu prawa procesowego - tak cywilnego, jak i administracyjnego na etapie wykonawczym. Podstawowa różnica ujawnia się, gdy zauważymy, że w nauce procesu cywilnego wypowiedzi obejmujące analizę zasad aktualnych w postępowaniu egzekucyjnym w kontekście teoretyczno-prawnym są mniej liczne i pogłębione niż w doktrynie administracyjnej. Najbardziej istotne odmienności ujawniają się dopiero w zakresie formułowania i porównania katalogu zasad sądowego i administracyjnego postępowania egzekucyjnego, co jest zrozumiałe, jeśli pamiętamy, że każda z omawianych procedur jest zaliczana do przeciwstawnych grup norm prawnych w ramach podziału prawa na publiczne i prywatne. Efektem tego jest podporządkowanie administracyjnego postępowania egzekucyjnego zasadzie obowiązkowego wszczęcia egzekucji, a sądowego postępowania egzekucyjnego zasadzie dyspozycyjności (rozporządzalności) ze wszystkimi dalszymi konsekwencjami w zakresie ukształtowania pozostałych przepisów procesowych.

\section{BIBLIOGRAFIA}

Berutowicz W., Postepowanie cywilne w zarysie, Warszawa 1984.

Błaszczak Ł., [w:] Postępowanie cywilne, red. E. Marszałkowska-Krześ, wyd. 2, Warszawa 2011.

Broniewicz W., Postępowanie cywilne w zarysie, Warszawa 2008.

Fundowicz S., Egzekucja administracyjna a aksjologia demokratycznego państwa prawnego, [w:] System egzekucji administracyjnej, red. J. Niczyporuk, S. Fundowicz, J. Radwanowicz, Warszawa 2004.

Hauser R., Ochrona obywatela w postępowaniu egzekucyjnym w administracji, Poznań 1988.

Hauser R., Skoczylas A., Rola zasad ogólnych postępowania administracyjnego w postępowaniu egzekucyjnym w administracji, [w:] Kodyfikacja postepowania administracyjnego. Na 50-lecie Kodeksu postępowania administracyjnego, red. J. Niczyporuk, Lublin 2010.

Janku Z., Gwarancje prawne wykonywania obowiązków publicznoprawnych, [w:] Koncepcja systemu prawa administracyjnego. Zjazd Katedr Prawa Administracyjnego i Postępowania Administracyjnego. Zakopane 24-27 września 2006 r., red. J. Zimmermann, Warszawa 2007.

Jodłowski J., Wstęp do systemu prawa procesowego cywilnego, [w:] Zbiór studiów, red. J. Jodłowski, Wrocław 1974.

Jodłowski J., Resich Z., Postępowanie cywilne, Warszawa 1987.

Kordela M., Zasady prawa. Studium teoretyczno-prawne, Poznań 2012.

Korzan K., Sadowe postepowanie zabezpieczające i egzekucyjne w sprawach cywilnych, Warszawa 1986. 
Korzonek J., Postępowanie egzekucyjne i zabezpieczające. Część druga kodeksu postępowania cywilnego, t. 1: Art. 508-597, Kraków 1934.

Kruszelnicki F., Zarys systemu polskiego prawa egzekucyjnego i zabezpieczajacego, Warszawa 1934.

Krzykowski P., Funkcje zasad ogólnych Kodeksu postępowania administracyjnego, [w:] Kodyfikacja postepowania administracyjnego. Na 50-lecie Kodeksu postepowania administracyjnego, red. J. Niczyporuk, Lublin 2010.

Marciniak A., Sadowe postępowanie egzekucyjne, wyd. 2, Warszawa 2013.

Maroń G., Zasady prawa. Pojmowanie i typologie a rola w wyktadni prawa i orzecznictwie konstytucyjnym, Poznań 2011.

Miszewski W., Proces cywilny w zarysie. Część druga, Łódź 1948.

Nowacki J., Tabor Z., Wstęp do prawoznawstwa, Warszawa 1994.

Piasecki K., Postepowanie sporne rozpoznawcze, Warszawa 2004.

Pogonowski P., Postępowanie zabezpieczajace i egzekucyjne, Warszawa 2007.

Redelbach A., Wronkowska S., Ziembiński Z., Zarys teorii państwa i prawa, Warszawa 1993.

Resich Z., Istota procesu cywilnego, Warszawa 1985.

Siedlecki W., Postępowanie cywilne. Zarys wykładu, Warszawa 1987.

Siedlecki W., Zasady wymiaru sprawiedliwości i naczelne zasady procesu cywilnego $w$ świetle orzecznictwa SN, „Zeszyty Naukowe IBPS” 1978, nr 10.

Skoczylas A., Zasady postepowania egzekucyjnego, [w:] System prawa administracyjnego, t. 9: Prawo procesowe administracyjne, red. B. Adamiak, J. Borkowski, A. Skoczylas, Warszawa 2010.

Smoktunowicz E., Egzekucja administracyjna i sądowa. Teksty, orzecznictwo, piśmiennictwo, indeks rzeczowy, Warszawa 1995.

Starościak J., Podstawowe zagadnienia postępowania egzekucyjnego w administracji, „Gospodarka i Administracja Terenowa" 1966, nr 7-8 (wkładka).

Szreniawski P., Etyczne aspekty egzekucji administracyjnej, [w:] System egzekucji administracyjnej, red. J. Niczyporuk, S. Fundowicz, J. Radwanowicz, Warszawa 2004.

Szubiakowski M., Zasady ogólne administracyjnego postępowania egzekucyjnego, [w:] System egzekucji administracyjnej, red. J. Niczyporuk, S. Fundowicz, J. Radwanowicz, Warszawa 2004.

Ustawa z dnia 14 czerwca 1960 r. - Kodeks postępowania administracyjnego (t.j. Dz. U. z 2013 r., poz. 267 z późn. zm.).

Ustawa z dnia 17 czerwca 1966 r. o postępowaniu egzekucyjnym w administracji (t.j. Dz. U. z 2005 r., nr 229, poz. 1954 z późn. zm.).

Wengerek E., Egzekucja sądowa (studium na tle projektu k.p.c. PRL), „Annales UMCS. Sectio G” 1957, Vol. IV, z. 4.

Wengerek E., Sądowe postępowanie egzekucyjne w sprawach cywilnych, Warszawa 1978.

Wyrok Naczelnego Sądu Administracyjnego z dnia 25 kwietnia 2003 r., III SA 2585/02, LEX nr 148901.

Wyrok Wojewódzkiego Sądu Administracyjnego w Gdańsku z dnia 15 kwietnia 2009 r., II SA/Gd 907/08, Baza NSA.

Wyrok Wojewódzkiego Sądu Administracyjnego w Gorzowie Wielkopolskim z dnia 30 października 2008 r., I SA/Go 678/08.

Ziemski K., Zasady ogólne prawa administracyjnego, Poznań 1989. 
Pobrane z czasopisma Studia Iuridica Lublinensia http://studiaiuridica.umes.pl Data: 26/04/2023 13:33:33

\section{SUMMARY}

This study attempts to present the issues of most important principles of judicial and administrative enforcement proceedings on a comparable basis. The authors discuss issues related to defining principles of the law against each of these procedures, indicate the criteria for distinguishing them and the role of the principles of law in making, interpreting and applying the law. Subsequently, problems of the lists of principles addressed in the doctrine of judicial and administrative enforcement proceedings were presented, stressing, at the same time, their individuality and specificity compared with other branches of the law. In the other part of the study the authors presented the analysis of the principle of dispositivness in court enforcement proceedings and the principle of compulsory initiation of administrative enforcement proceedings, and therefore, the principles that best illustrate the dissimilarity of rules governing the public and private law enforcement.

Keywords: dispositive principle; general provisions; administrative enforcement proceedings; court enforcement proceeding 